\title{
Growth of Lettuce (Lactuca sativa L.) Plant in Light Organic Fertilizer Media From Goat and Rabbit Dirty
}

\author{
Kusuma Wardany ${ }^{1}$, Sulis Anjarwati ${ }^{2}$ \\ ${ }^{1,2}$ Biology Education, Nahdlatul Ulama University of Lampung, Indonesia \\ kㅏ.
}

\begin{abstract}
Keyword:

Goat Droppings, Rabbit Droppings, Liquid Organic, Growth Of Lettuce.

Goat droppings and rabbit droppings are types of animal droppings that have not been maximally utilized. If treated with both types of impurities can produce liquid organic fertilizer that can be used in agriculture. The purpose of this study was to determine the effect of liquid organic fertilizer from goat manure and rabbit manure on the growth of lettuce (Lactuca sativa L.). This research was carried out in the agricultural land in the rice field area of Purbolinggo District, East Lampung.The method used in this study was an experiment using a completely randomized design (CRD) pattern of one factor, namely the type of liquid organic fertilizer from goat manure and rabbit feces three times. The data obtained were analyzed by quantitative descriptive analysis. The best treatment for stem height growth is P1 (liquid fertilizer of $500 \mathrm{ml}$ goat manure), with an average growth of $1.8 \mathrm{~cm}$ for one month. The best treatment for the number of leaves is P2 (500 $\mathrm{ml}$ rabbit manure liquid fertilizer), with an average growth of 4 leave.
\end{abstract}

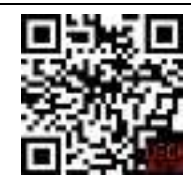

\section{Article History:}

Received: $31-01-2020$

Revised : 19-03-2020

Accepted: 06-04-2020

Online : 09-04-2020

\author{
(a) (1) (2) \\ This is an open access article under the CC-BY-SA license \\ crossref \\ https://doi.org/10.31764/ijeca.v3i1.2043
}

\section{A. INTRODUCTION}

The use of fertilizer in Indonesia continues to increase in accordance with the increase in agricultural area, population growth, and the increasingly diverse use of fertilizer as an effort to increase agricultural output. One of the efforts that can be done to increase the production of vegetable crops is by providing fertilizer. Fertilization is done in order to meet the nutrient requirements for plants, so as to provide high yields (Manullang, 2018).

Goat solid waste is one type of animal dung whose utilization is not so optimal. People usually directly use goat manure as fertilizer for plants without going through processing first, so plants that are fertilized with goat manure cannot grow optimally because goat manure has a fairly hard structure and is long broken down by soil. One alternative treatment for goat solid waste is to be made as liquid fertilizer. The use of organic fertilizers can be a solution in reducing the excessive use of inorganic fertilizers. However, the weakness of organic fertilizer in general is the low nutrient content and is slowly available to plants. Organic fertilizers can be either solid or liquid. The advantage of liquid organic fertilizer is that the nutrients it contains are more readily available and are easily absorbed by plant roots (Pardosi et al., 2014).

According to Supardi's research, liquid organic fertilizer provides several advantages, for example, this fertilizer can be used in solid, growing media by spraying it to the roots or 
spraying it on plant parts of the plant, but on liquid planting media (hydroponic) has not been further investigated. (Fitriyatno et al., 2011)

Lettuce is a vegetable in the form of leaves that are favored by the people who are usually consumed fresh as fresh vegetables. Lettuce is usually used as a food mixture in salads, burgers, gado-gado and fried rice. Inside the lettuce there is an iron content. According to USDA data (U.S. Department of Agriculture (USDA), 2014) in the study of Zuhaida, it states that in 100 $\mathrm{g}$ of lettuce there is an iron content of about $0.86 \mathrm{mg}$. Iron is very useful to the human body. Iron deficiency will cause anemia, which is characterized by pale, tired, weak and reduced vision. (Zuhaida, 2013)

Lettuce plants can grow in the lowlands and in the highlands. Optimal growth for lettuce is on fertile land containing lots of growth and production of lettuce in the provision of various types of organic fertilizer, humus, sand or mud with a soil $\mathrm{pH}$ of 5-6.5. Lettuce (Lactuca sativa L.) plant is one of the plants vegetables that are included in the Compositae family (Sunarjono, 2005). Lettuce leaves have different shapes, sizes and colors depending on the variety. The height of the lettuce plant ranges from $30-40 \mathrm{~cm}$ and the height of the lettuce plant ranges between $20-30 \mathrm{~cm}$. Lettuce has a rooting and fibrous root system. Fiber roots attach to the stem and grow to spread in all directions at a depth of $20-50 \mathrm{~cm}$ or more (Fitriyatno et al., 2011).

Lettuce cultivation with organic fertilizer is usually done by farmers by using manure (pukan) which can add soil nutrients and improve soil physical properties. Organic fertilizer is fertilizer that comes from the remains of plants and animals or humans, for example, such as manure (pukan), green manure, and compost in both liquid and solid forms. One of the effects of the application of organic fertilizer on plants is to increase the activity of microorganisms, so that the activities of organisms in breaking down organic matter can increase nutrients in the soil and become available to plants (Hardinsyah \& Aries, 2012).

Research conducted by Syahputra, which examined the effect of the composition of the planting media and the concentration of leaf fertilizer on the growth and yield of lettuce (Lactuca sativa L.) that to increase the growth and yield of lettuce plants that grow in the lowlands, the right planting media is needed and sufficient nutrient availability. Nutrients in the available form will be more quickly absorbed by plants for use in metabolism so that it will respond to plant growth and development. (Syahputra, 2014).

\section{B. METHODS}

This research was conducted on agricultural land in the District of Purbolingo, East Lampung district. This research was conducted on October 15 to October 30 2019. The tools and materials used in this study were scales, $6000 \mathrm{ml}$ volume plastic buckets, measuring cups, stirrers, $1500 \mathrm{ml}$ used aqua bottles, filters, dipper, net pots, trays, stationery (ballpoints, rulers and books). The materials used are goat dung, rabbit dung, lettuce seeds, flannel cloth, label paper and water. The experimental design used was a completely randomized design (CRD) pattern of one factor, namely liquid fertilizer (P) with 3 replications, namely P1 (liquid fertilizer of goat manure volume of $500 \mathrm{ml}$ ) and P2 (liquid fertilizer of rabbit manure volume of $500 \mathrm{ml}$ ).

This type of research is quantitative research. Data collection methods consist of methods of experimentation, observation, documentation and literature review. Data were analyzed using quantitative descriptive analysis. Quantitative descriptions are used to test the vegetative growth of lettuce from different types of fertilizers and the same volume.

\section{RESULT AND DISCUSSION}

\section{Bar Height}

Based on observations of the growth of lettuce height with $500 \mathrm{ml}$ goat manure liquid volume and $500 \mathrm{ml}$ rabbit manure liquid fertilizer on lettuce vegetative growth, IE stem height and number of leaves from week 0 (initial planting) to 4 th week (Table 1). 
Table 1. Average growth of stem height $(\mathrm{cm})$ of lettuce on liquid fertilizer medium goat manure and rabbit manure with a volume of $500 \mathrm{ml}$ within 1 month.

\begin{tabular}{lccc}
\hline \multicolumn{1}{c}{ Treatment } & Week-0 & Week-4 & Accretion \\
\hline Liquid fertilizer for goat manure $500 \mathrm{ml}(\mathrm{P} 1)$ & 1,4 & 3 & 1,8 \\
Liquid fertilizer for rabbit droppings $500 \mathrm{ml}(\mathrm{P} 2)$ & 1,7 & 2,9 & 1,4 \\
\hline
\end{tabular}

\section{Number of Leaves}

Based on observations of growth in the number of leaves of lettuce by applying $500 \mathrm{ml}$ goat manure liquid fertilizer and $500 \mathrm{ml}$ rabbit manure liquid fertilizer from week 0 (initial planting) to week 4 (Table 2).

Table 2. Average growth of the number of leaves of lettuce on liquid fertilizer medium goat manure and rabbit manure with a volume of $500 \mathrm{ml}$ within 1 month

\begin{tabular}{lccc}
\hline \multicolumn{1}{c}{ Treatment } & Week-0 & Week-4 & Accretion \\
\hline Liquid fertilizer for goat manure $500 \mathrm{ml} \mathrm{(P1)}$ & 3 & 5 & 3 \\
Liquid fertilizer for rabbit droppings $500 \mathrm{ml}(\mathrm{P} 2)$ & 3 & 6 & 4 \\
\hline
\end{tabular}

Based on Table 1 shows that the best height growth of lettuce stems is P1 (liquid fertilizer of goat manure $500 \mathrm{ml}$ ) which is $1.8 \mathrm{~cm}$, while the lowest growth height of lettuce stems is P2 (liquid fertilizer of rabbit manure $500 \mathrm{ml}$ ) which is $1.4 \mathrm{~cm}$. This is because the element $\mathrm{K}$ in goat manure is higher than that of rabbit manure. In goat manure, element $\mathrm{K}$ was $3.5 \%$, while rabbit manure was $1.86 \%$. Potassium for plants has an important function in enzyme reactions, cell $\mathrm{pH}$ regulation, cell cation-anion balance, stomatal transpiration regulation.Therefore, nutrient $\mathrm{K}$ plays a role in the formation of enzymes and proteins, as well as water efficiency through the opening of stomata. K deficiency in plants causes stunted plants (Taiz \& Zeiger, 2010).

Insignificant results in the growth of lettuce stem height can be seen from plant morphology. The results of the observation showed that the plants looked stunted. This is because organic matter is a source of nutrients N, P, and K which can stimulate plant growth. Growth of stem length and diameter requires nutrients $\mathrm{N}, \mathrm{P}$ and $\mathrm{K}$. $\mathrm{N}$ compounds contained in organic matter play an optimal role in amino acid and protein synthesis, then used in the process of plant growth and development, whereas plants that lack $\mathrm{N}$ nutrients cause plants become stunted (Safuan \& Bahrun, 2012). Hara P mainly plays a role in the transfer and storage of energy, as well as maintaining membrane integrity, cell division and enlargement. This element can stimulate root growth and development, so plants are more resistant to drought. P element deficiency in plants causes dwarf plants.

Stem height is the easiest indicator of growth to measure. The elongation rate of stems differs between species and is influenced by the environment in which the plant grows. Stem height growth is influenced by internal and external factors. Internal factors are heredity and hormones, while external factors are obtained from the environment, namely temperature and light intensity. Light or sunlight is very important for plant growth and development. Light or sunlight is needed for photosynthesis. This research was conducted in February to coincide with the rainy season, the sunlight was less than optimal so that the growth of lettuce plants was hampered.

Based on Table 2, the best growth in the number of leaves of lettuce is P2 (liquid fertilizer for rabbit manure $500 \mathrm{ml}$ ) which is 4 leaves and the lowest is P1 (liquid fertilizer for goat manure $500 \mathrm{ml}$ ) which is 3 leaves. Based on the results of growth in the number of lettuce leaves, in plants treated with $500 \mathrm{ml}$ rabbit manure liquid fertilizer, the growth tends to be better when compared to the treatment of goat fertilizer even though the volume is the same.

The yield of lettuce is in the leaves, so the fertilizer given should contain a lot of nitrogen $(\mathrm{N})$. This can be related to the nature of the supply of nutrients to plants, because if the nutrients supplied to plants in excess of the amount needed by plants will actually cause plants to grow less than optimal. The nutrient that plays a role in the number of leaves is nitrogen $(\mathrm{N})$. In rabbit 
dung contained nitrogen $(\mathrm{N})$ nutrients of $2.62 \%$, while rabbits $2.45 \%$. So that more leaves are treated with rabbit droppings than goat droppings.

Based on research conducted by Mas'ud higher content of nitrogen ( $N$ ) in homemade nutrients spurred an increase in the number of leaves and height of lettuce compared to the $A B$ mix nutrition. The function of nitrogen stimulates plant growth and gives the leaves a green colour. Nitrogen is more common in young tissue than in old plant tissue, mainly accumulating in leaves and seeds. The leaves turn yellow or yellowish green and tend to fall out quickly if the $\mathrm{N}$ elements are not met. If giving excessive $\mathrm{N}$ to the plant will slow the maturity of the plants, the stems are weak, easy to collapse and the plant's resistance to disease is reduced. Iron ( $\mathrm{Fe}$ ) functions for plant respiration and leaf green formation (Mas'ud, 2002).

\section{CONCLUSION AND SUGGESTIONS}

Based on the discussion, the following conclusions can be drawn: (1) There is a medium effect of liquid organic fertilizer from goat manure and rabbit manure, where liquid fertilizer for rabbit manure is more effective at growing the number of leaves, while goat manure is more effective in stem height growth. (2) The best treatment for stem height is P1 (liquid fertilizer of $500 \mathrm{ml}$ goat manure) which is $1.8 \mathrm{~cm}$. The best treatment for the number of leaves is $\mathrm{P} 2(500 \mathrm{ml}$ rabbit manure liquid fertilizer), which is 4 leaves. (3) Based on the discusion, the following suggestions can be drawn: further research needs to be done to determine the dose of goat manure and rabbit manure which produce the best results as an alternative nutrient for the growth of lettuce plants.

\section{REFERENCES}

Fitriyatno, Suparti, \& Anif, S. (2011). Uji Pupuk Organik Cair Dari Limbah Pasar Terhadap Pertumbuhan Tanaman Selada (Lactuca sativa L) Dengan Media Hidroponik. Prosiding Seminar Nasional IX Pendidikan Biologi FKIP UNS, 635-641.

Hardinsyah, \& Aries, M. (2012). Jenis Pangan Sarapan Dan Perannya Dalam Asupan Gizi Harian. Jurnal Gizi Dan Pangan, 7(2), 89-96.

Manullang, B. (2018). Pengaruh Strategi Pembelajaran Berbasis Media Interaktif Dan Gaya Berpikir Terhadap Kompetensi Teknologi Pengolahan Hasil Pertanian. Jurnal Teknologi Informasi \& Komunikasi Dalam Pendidikan, 4(2). https://doi.org/10.24114/jtikp.v4i2.8759

Mas'ud, A. (2002). Efektifitas Trap Warna Terhadap Keberadaan Serangga Pada Pertanaman Budidaya Cabai di Kelurahan Sulamadaha Kecamatan P. Ternate. Journal of Chemical Information and Modeling, 53, 159. https://doi.org/10.1017/CB09781107415324.004

Pardosi, A. H., Irianto, \& Mukhsin. (2014). Respons Tanaman Sawi terhadap Pupuk Organik Cair Limbah Sayuran pada Lahan Kering. Prosiding Seminar Nasional Lahan Suboptimal, September, 979-587.

Pengaruh Komposisi Media Tanam Dan Konsentrasi Pupuk Daun Terhadap Pertumbuhan Dan Hasil Tanaman Selada (Lactuca sativa L.). 9(1), 39-45. https://doi.org/10.24815/floratek.v9i1.1375

Pertumbuhan dan Hasil Selada (Lactuca sativa L.) Hidroponik Diperkaya Fe. (2013). Pertumbuhan Dan Hasil Selada (Lactuca Sativa L.) Hidroponik Diperkaya Fe, 1(4), 68-77. https://doi.org/10.22146/veg.1597

Safuan, L. O., \& Bahrun. (2012). Pengaruh Bahan Organik Dan Pupuk Kalium Terhadap Pertumbuhan Dan Produksi Tanaman Melon (Cucumis melo L .). Jurnal Agroteknos, 2(2), 69-76. http://faperta.uho.ac.id/agroteknos/Daftar_Jurnal/2012/2012-2-02-SAFUAN.pdf

Sunarjono, H. (2005). Sirsak \& Srikaya. In Niaga Swadaya. https://doi.org/10.12928/kesmas.v4i3.1093

Taiz, L., \& Zeiger, E. (2010). Photosynthesis: Carbon Reactions. Plant Physiology, 145-170.

U.S. Department of Agriculture (USDA), A. R. S. (2014). USDA National Nutrient Database for Standard Reference, Release 27. In Database. http://www.ars.usda.gov/nutrientdata 